Copyright (C) 2021 The Author/s

This work is licensed under a CC-BY 3.0 License

Peer review method: Double-Blind

Accepted: August 24, 2021

Published: September 21, 2021

Original scientific article

DOI: https://doi.org/10.47305/JLIA2137157a

\title{
THE LEADERSHIP REQUIREMENT OF THE CRIME OF AGGRESSION UNDER THE ROME STATUTE OF THE INTERNATIONAL CRIMINAL COURT
}

\author{
Faruk H. Avdic \\ Independent Researcher, Bosnia and Herzegovina \\ ORCID iD: https://orcid.org/0000-0001-7567-5588 \\ hadziavdicfaruk@gmail.com
}

\begin{abstract}
The subject of this analysis was the provisions of the Rome Statute of the International Criminal Court devoted to the leadership requirement of the crime of aggression. The crime in question is the successor of crimes against peace. This paper employed normative and formal dogmatic legal methods in analyzing the particulars of the leadership clause. Besides, this analysis also took into consideration the case-law of certain judicial bodies. This paper aimed to examine whether the leadership requirement of the crime of aggression has been properly constructed for the Statute. The main focus was on the meaning of the conditions stemming from the leadership clause that each perpetrator ought to fulfill to incur criminal responsibility for the crime of aggression. Additionally, this research addressed the criminal responsibility of public and private actors and the modes of participation in the crime in question. The article established that the leadership requirement concerning the crime of aggression has been aptly incorporated in the Statute since this requirement, at the same time, embraces the post World War Two standards concerning crimes against peace and the contemporary notion of aggression as one of the core crimes under international law.
\end{abstract}

Keywords: Aggression; Leadership; Effectiveness; Criminal Responsibility

\section{INTRODUCTION}

The adoption of the amendments to the Rome Statute (hereinafter: the Statute) ${ }^{1}$ of the International Criminal Court (hereinafter: the Court) concerning the crime of aggression at the 2010 Review Conference in Kampala is without any doubt a historic achievement comparable to the adoption in 1998 of the Statute itself (Blokker and Kress 2010, 889-895). It is worth observing that for the first time in the history of mankind, after the prosecutions of German and Japanese war criminals in the aftermath of the Second World War, there is an international court with the jurisdiction to try the perpetrators of the crime of aggression, which is a familiar concept in international

\footnotetext{
${ }^{1}$ All articles mentioned in this paper refer to the Rome Statute of the International Criminal Court unless otherwise emphasised.
} 
criminal law. International criminal law understood in the modern sense starts with the prosecution of Nazi Party officials and high-ranking military officers along with German industrialists, lawyers, and even doctors. Military tribunals, among other things, dealt with the criminal prosecution of the German and Japanese defendants accused of crimes against peace which is equivalent to the crime of aggression. However, the Charter of the International Military Tribunal (hereinafter: the IMT) and the Charter of the International Military Tribunal for the Far East modeled after the former remained silent about the individual conduct and mental elements of crimes against peace (McDougall 2016, 80). The London and Tokyo Charters did not stipulate the capacities or properties of the perpetrator of crimes against peace or any other crimes.

Nonetheless, in the view of the military tribunals trying Nazi and Japanese war criminals, crimes against peace were not considered delictum communium since the perpetrator ought to fulfill the so-called 'leadership requirement' to be held criminally responsible for these crimes. When it comes to the leadership requirement of crimes against peace, this requirement was first introduced in the Farben case concerning waging aggressive war (Heller 2011, 184). The US Military Tribunal in the Farben case held that criminal responsibility for crimes against peace was confined to those "responsible for the formulation and execution of policies" (USA v. Carl Krauch et al. Trials of War Criminals Before the Nuremberg Military Tribunals Under Control Council Law No. 10 (1952), Vols. VII-VIII (Farben case), 1123).

Before the Farben case, however, the Tribunal in the High Command case held that a person's rank or status is not a conclusive or isolated factor in establishing his criminal responsibility for crimes against peace "but his power to shape or influence the policy of his State" (USA v. Wilhelm von Leeb et al. Trials of War Criminals Before the Nuremberg Military Tribunals Under Control Council Law No. 10 (1951), Vols. X-XI (High Command case), 486). The same Tribunal also held that actions of those, who as a consequence of their actual power to shape and influence the policy of their nation, prepare for, or lead their country into or in an aggressive war, is condemned under international law (High Command case, 486). The Tribunal also acknowledged that the actions of those who simply act as the instruments in the hands of the policy-makers are not criminalized at the present stage of the development of international law (High Command case, 486). In this excerpt from the reasoning, we can observe the contours of the crime of aggression and the leadership requirement in their rudimentary form.

First and foremost, even though the formal status or rank of the perpetrator was not a decisive factor, the perpetrator had to have the power to shape or influence the policy of his State or to formulate or execute such policies. In other words, crimes against peace could not have been committed by any perpetrator. In the second place, crimes against peace were considered crimes under international law at that time. Last but not least, only certain categories of individuals who could satisfy the requirements of shape or influence could be held criminally responsible for crimes against peace. 
It is clear from this that crimes against peace were considered to be the crime of leadership albeit not the formal one that would be reflected in holding public office. After a brief turn to the post-WWII understanding of crimes against peace, we will now devote our attention to the crime of aggression in contemporary international criminal law. The definition of the crime in question and the conditions for criminal prosecution of individuals in front of the Court were the issues of significant discussions at the negotiations of the Statute since the criminalization of aggression directly concerns state sovereignty and presuppose the establishment of individual responsibility attributable to high-ranking political and military leaders (Fujita 2006, 40). Even though it took the States Parties twelve years from the establishment of the Court in 1998 to reach a compromise regarding the definition of the crime of aggression, the States Parties finally succeeded in 2010. In connection with that, according to the newly added article 8 bis of the Statute:

For the purpose of this Statute, 'crime of aggression' means the planning, preparation, initiation or execution, by a person in a position effectively to exercise control over or to direct the political or military action of a State, of an act of aggression which, by its character, gravity, and scale, constitutes a manifest violation of the Charter of the United Nations.

The nature of the crime of aggression is accordingly dual. The criminal offense in question comprises the conduct of an individual and the act of an aggressor State. It is clear from the intrinsic peculiarities of aggression that single individuals acting without coordination cannot commit such a crime - instead, it always results from the collective action of a plurality of persons (Cassese 2007a, 848). Secondly, the crime in question is attributable to "political and military leaders and other senior state officials" who "mastermind, plan, or organize" this crime (Cassese 2007a). According to the Statute, the crime of aggression cannot occur without the involvement of a State. Hence, here lies the difference between the crime of aggression and other core crimes. While it is hard to imagine the commission of genocide, crimes against humanity, and war crimes, without significant State involvement, these crimes can be committed by non-state actors.

The leadership requirement is thus an integral part of the definition of the crime in question contained in the Statute, and it is one of its special features. The leadership clause repeats itself in the general part of the Statute that governs modes of criminal responsibility for perpetrators and their accomplices for participation in the crime of aggression. The Elements of Crimes (hereinafter: the Elements) also contain the leadership clause about the crime of aggression. The leadership requirement is thus an objective element of the crime in question that can be considered a conduct element or a circumstance element depending on the particulars of each specific individual crime of aggression (Clark 2009a, 679). This requirement distinguishes the crime in question from 
the other crimes within the purview of the Court, namely, genocide, crimes against humanity, and war crimes.

\section{THE EFFECTIVENESS TEST}

One of the crucial issues regarding the crime of aggression is whether the perpetrator had been in a position to effectively control or direct political or military action of a State. Hence, comprehensively understanding the crime of aggression requires assessing the level of control over a political or military action that the perpetrator has to wield. Nevertheless, the Statute has not followed the post-WWII precedents regarding the factual relationship between the perpetrator and the crime of aggression. The prosecutors charged with the prosecution of the German and Japanese warlords in the aftermath of World War II had been in a more comfortable position regarding proving the commission of the crime of aggression compared to the potential future situation faced by the prosecutor proceeding in front of the Court.

As we have seen, the statutory definition of the crime of aggression requires that the perpetrator has been a person in a position to execute the requisite conduct, namely, to control or direct political or military action of a State. Therefore, the essence of the leadership requirement is that the perpetrator occupied a defined role at the time of the commission of the criminal offense regardless of whether he had found himself in that role voluntary or involuntary from his perspective (Clark 2009a, loc. cit.). However, there are different interpretations of this requirement. According to the first, also narrower understanding, the individual in question must have occupied a position that formally incorporates the ability to exercise control over or direct the political or military action of a State (McDougall 2015, 179).

On the other hand, according to the second, more extensive understanding, the phrase in a position amounts to the mere actual ability to execute the required conduct that does not need to stem from a constitution of another legal instrument of lesser legal strength. In many cases, besides occupying the governmental post or another official role, the perpetrator would also possess the informal power to exercise significant influence over the politics of a State. Therefore, a person could satisfy the leadership requirement when he can influence political processes and State behavior despite the lack of any official capacity.

The extension of the leadership clause to those who do not hold any public office seemingly extends the boundaries of punishability for the crime of aggression. However, on close examination, the insistence on a factual power rather than a formal status or rank has the opposite effect since it excludes from the potential category of perpetrators those members of the formal governmental power structure who cannot exercise real power, such as, for instance, heads of States who are mere figureheads deprived under their national legislation of actual power to influence policies of their 
States (Clark 2009b, 715). The incorporation of the term 'effectively' in the leadership clause indicates that mere de jure power over the political or military action of a State would not satisfy the leadership requirement and that a real capacity of exercising power must be established. An example of a figurehead with de jure powers but left with no actual control is the British Queen concerning the political and military establishments in Canada, Australia, and New Zealand (Gillet 2013, 860).

In case of criminal prosecution of the leaders of any of these former colonies for the crime of aggression, the Queen could not face any potential criminal responsibility as she lacks sufficient power or control to fulfill the requirements stemming from the leadership clause concerning these countries (Gillet 2013). The problem is that neither the Statute nor the Elements offer any additional explanation concerning the level of requisite control (Gillet 2013). The satisfaction of the leadership requirement will thus depend on the circumstances of each particular case (Gillet 2013).

The Statute, nonetheless, when defining the crime of aggression, did not opt to borrow the shape or influence test devised in the post-WWII trials. In this regard, adopting the control or direct phrase presents a departure from the post-WWII standard concerning the criterion for attributing criminal responsibility to the perpetrator for the crime of aggression. When amending the Statute in 2010, the State Parties injected the standard of effectiveness into the statutory definition of the crime of aggression. The issue arising from the effectiveness standard stems from the fact that this standard is the legal transplant into the Statute previously employed in an unrelated legal context (Weisboard 2009, 47). Therefore, taking into account the fact that the standard of effectiveness is in the first place the creature of public international law, we are ought to leave the boundaries of international criminal law and step into the field of public international law to discuss the abovementioned standard and its implications and repercussions. 'Effective control' is the standard that the International Court of Justice (hereinafter: the International Court) used in 1986 to assess whether the United States of America had been responsible for acts carried out by Contra guerillas in Nicaragua (Military and Paramilitary Activities in and Against Nicaragua (Nicar. v. US, 1986 I.C.J. 14, June 27). After rejecting that the Contras were de facto organs of the United States, the International Court held that the responsibility of the United States could still arise if it were proved that it had itself "directed or enforced the perpetration of the acts contrary to human rights and humanitarian law alleged by the applicant State" (Nicar. v. the US, 64). In the same case, the International Court illustrated further, "for this conduct to give rise to the legal responsibility of the United States, it would in principle have to be proved that that State had effective control of the military or paramilitary operations in the course of which the alleged violations were committed" (Nicar. v. the US, 65).

Albeit the International Court failed to define the test of effective control further it can be concluded that the test requires that the involvement of the external entity consists "in planning the operation, choosing targets, giving specific directives and 
instructions, and providing operational support" (Talmon 2009, 503). It seems clear from these words that by 'effective control' the Court meant either (1) the issuance of directions to the controlled subject by the subject wielding power over the former concerning specific operations, that is to say, the ordering of those operations, or (2) the enforcement by the entity exercising control over each specific operation of the subordinate subject, namely forcefully making the latter to carry out specific operations (Cassese 2007b, 653).

The effective control test has been applied in international criminal proceedings as well. The International Criminal Tribunal for the former Yugoslavia (hereinafter: the ICTY) in Tadic examined different degrees of control. However, the Appeals Chamber of ICTY in Tadic took a different view regarding the control required. The Appeals Chamber of the ICTY in the Tadic case differentiated between two categories of de facto state organs whose actions give rise to State responsibility under international law. In addition to the test of effective control, the ICTY added the test of overall control.

The ICTY differentiated between two situations regarding the control test. In the first hypothetical situation, individuals act on behalf of a State without specific instructions. In the second hypothetical situation, by contrast, individuals comprise an organized and hierarchically structured group, such as a military unit or, in case of war or civil strife, armed bands of irregulars or rebels (Prosecutor v. Dusko Tadic, Case No. IT-94-1-A, Judgment of the Appeals Chamber, 15 July 1999 (Tadic case), 120). Unlike an individual, an organized group differs from the former since such a group has a structure, a chain of command, and a set of rules as well as the outward symbols of authority (Tadic case, 120). A member of the group, as a rule, does not act on his own but conforms to the standards prevailing in the group and is subject to the authority of the head of the group (Tadic case, 120). Thus, for the attribution to a State of acts of these groups according to the Tadic case, it is sufficient to require that the group as a whole is under the overall control of the State (Tadic case, 120).

As we have seen, in the Tadic case, the ICTY employed the overall control test to attribute responsibility under international law to States for the acts of unofficial state agents. In the same vein, the overall control test suffers from the same flaw as the effective control test in that both of them are devised and applied in different legal contexts and with other purposes than establishing the responsibility of individuals for crimes. Hence, international criminal law is not the natural habitat of effective control or overall control. In international criminal law, the test of effective control would have to flow in an opposite direction from the direction in which have been initially devised and applied.

The International Court nevertheless remained faithful to the test of effective control and relied upon it in the Bosnian Genocide case when the International Court again employed the test to establish the responsibility of a State under international law for actions of a non-state actor (Cassese 2007b, 649-668). 
In the Bosnian Genocide case, despite acknowledging that the test of overall control could be appropriate in different contexts from assessing the responsibility of States, the International Court characterized the overall control test as unsuitable for attributing responsibility under international law to a State since the responsibility derived based on such a test would be overly broad in any event (Crawford 2013, 155). The standard of effectiveness implanted in the Statute about the ability of the perpetrator of the crime of aggression to control or direct the action of a State has nevertheless come under harsh criticism. Weisbord (2009, loc. cit.) acknowledges that even though effective control is a sociologically appropriate evolution from a formal position because it captures crucial contemporary aspects of leadership, it suffers from two shortcomings as a property of the leadership qualifier for the crime of aggression. In the first place, this author points out that the effective control test has been transplanted into the Statue which deals with the issues of international criminal law, while the mentioned test hails from public international law (Weisbord 2009).

In the second place, according to the same author, the standard of effective control does not extend far enough to cover the criminal responsibility of the leaders of post-bureaucratic organizations (Weisbord 2009). Additionally, other authors join in the criticism of the effective control concept, albeit from different perspectives. Cassese (2007b, 651-653), while finding the test itself as unpersuasive, bases his criticism of the abovementioned test on the fact that it neither reflects international customary law nor the practice of states since the test is the invention of the International Court and its judicial creativity in the cited Nicaragua case and thus grounded of the authority of the International Court itself. Another argument put forward against the leadership requirement is that the proving of "an absolute leadership requirement" as regards the ability to control or direct the action of a State would be an onerous task, which could impede the capabilities of national criminal justice systems to effectively outroot the systemic causes of the crime of aggression since the leadership clause from the Statute would significantly motivate national law-making bodies to alter their criminal codes about the crime of aggression to make them in line with the Statutory definition of crime in question (Drumbl 2009, 314).

The formula contained in the leadership clause of the crime of aggression has been criticized as too narrow since exempts from criminal responsibility those who even though they do not hold public offices on the one hand, nevertheless could contribute strongly to the act of aggression on the other (Clark 2009b, loc. cit.). According to Heller (2011, 379), as a result of pairing up effective with control in the text of the Statute, such a considerably more restrictive standard than shape or influence saves from criminal prosecution private economic actors such as industrialists, even though the military tribunals maintained that such figures could be held criminally responsible for their participation in the crime of aggression. Albeit one should give credit to those arguments concerning inappropriateness and shortcomings of the effectiveness 
standard, the standard in question is nonetheless the apt solution regarding the attribution of criminal responsibility for the crime of aggression to the individual perpetrator. Even though the overall control test may be satisfactory when it comes to the attribution of international responsibility to States for the actions of their agents, such a test would certainly and unnecessarily extend the criminalization for the crime of aggression to many mid-ranking and even low-ranking participants in the crime of aggression. In adopting the effective control or direct criterion, the Statute had rejected the Nirenberg legacy of shape or influence and, at the same time, acknowledged that the boundaries of criminalization should and must be clearly defined since the law governing behavior that gives rise to criminal responsibility has to be foreseeable so that each concerned individual know how he should behave himself.

The standard of shape or influence leaves too much leeway for different interpretations when it comes to the issue of who can satisfy such a standard. This standard is a fairly elastic expression (Dinstein 2011, 143). In democracies where countless bureaucrats and military officials take part in shaping the policies of a State or its military actions, an excessively large group of people would be able to satisfy this standard and unjustifiably face criminal prosecution (Ambos 2014, 205). Hence, adopting the overall control test or shape or influence standard or another less stringent standard and thus broadening individual criminal responsibility would not be consistent with the contemporary developments of international criminal law (Hajdin 2017, 565566).

Also, we should bear in mind that the State is a hierarchically structured organization with clearly defined roles of its officeholders and civil servants and military personnel. One should not incur criminal responsibility because he had occupied a position allowing him to exert influence on the conduct or policy of a State. In connection with that, the mere possibility of influencing even significantly the decisionmaking process resulting in the commission of the crime of aggression does not satisfy the effectiveness standard required by the Statute. The test of effectiveness about the ability to control or direct the political or military action of a State is satisfied when the conduct of a State giving rise to criminal responsibility for the crime of aggression could not have occurred without the commission or omission of the perpetrator (Hajdin 2017, 562-563). The effective control test in the context of criminal responsibility for the crime of aggression requires that the perpetrator holds power to decisively exert influence over the behavior of a State that results in the commission of the act of aggression. This influence consists in the capability of the perpetrator to order the execution of specific actions of political or military state machinery or to forcefully make others execute such actions. Also, one should point out that the phrase "by a person in a position effectively to exercise control over or to direct the political or military action of a State" (article 8 bis (1) of the Statute) has certain shortcomings, and thus one should not read and, what is more significant, interpret this phrase literally. 
First and foremost, the cited provision does not mean that the individual bears criminal responsibility for the crime in question when he can effectively control or direct the political or military action of a State. For example, a high-ranking general has the possibility, by a virtue of his military rank, to exercise effective influence over or direct military action, but this does not make him the perpetrator in the commission of the crime. Also, politicians, especially high-ranking ones, can control political actions according to national legislation. However, this would not make them criminally responsible for the crime of aggression. In a hypothetical situation, a defense minister as a member of the government may have a possibility to exercise effective control over political or military actions but cannot incur criminal responsibility if he did not exercise such control over the action that resulted in aggression. The prerequisite for criminal responsibility is a causal relationship between the ability of the perpetrator to exercise control or direct the action of a State, on the one hand, and the crime of aggression on the other hand. In other words, there must be a link between a political, military, or another position the perpetrator occupies on the one hand, and the action of a State giving rise to criminal responsibility for the crime of aggression on the other (Zimmermann and Freiburg 2015, 592).

The control required for the attribution of criminal responsibility for the crime of aggression thus must be effective regarding its level. Nevertheless, one should not, in any case, assume that the control test is satisfied only when all the control is concentrated in the hands of one person occupying the highest position at the top of the government (Volker 2017, 46). Unified control over the employment of military force belonging to one person can hardly occur even in the most autocratic regimes (Reisinger Coracini and Wrange 2016, 311).

Hence, the control test is met in the case when control is distributed between different public officials and those acting in the private capacity, on the condition that they can dominate over the political or military actions of a State. In western democracies or countries whose governments are modeled after them, especially those with checks and balances, a single individual cannot acquire and maintain unified control. For example, even in the presidential system, where there is no government in a narrow sense, the president does not have the authority to unilaterally and autonomously decide on waging war, but he needs official authorization from the legislative body. Therefore, equating effective with unified or absolute control would be inconsistent with international (customary) law, constitutional theories, and the letter and the spirit of the Statute.

In sum, even though the test of effectiveness is an apt solution for the Statute, there is, nonetheless, no doubt that the standard of effective control raises the bar for criminal prosecution and conviction since requiring effective control over the specific acts in question is a very demanding threshold. 


\section{THE CAPACITY OF THE PERPETRATOR: PUBLIC ACTORS}

When defining each criminal offense, one of the essential questions is who can be criminally responsible for the criminal offense in question, namely, does the perpetrator have to act in a specific capacity or to possess certain features differentiating him from others or the perpetrator can be any person regardless of a role in which he committed a crime or his personal properties. Before delving deeper into the leadership requirement of the crime in question, we should bear in mind that modern international criminal law, fortunately, does not turn a blind eye toward the wrongdoing of those who enjoy immunity under international or municipal law. According to article 27 (1), the Statute applies without any discrimination to all individuals without any distinctions based on their official capacity. In other words, the Statute applies regardless of the official status of the perpetrator, which means that official capacity does not absolve the perpetrator from criminal responsibility and subsequent criminal prosecution.

Because of the leadership requirement, the crime of aggression is not only a state crime, but it is also a crime of the highest state political and military leadership. The Statute has envisioned the crime of aggression as a leadership crime attributable only to specific categories of perpetrators who satisfy the prescribed requirements laid down in its text. According to article 8 bis (1) of the Statute, the crime of aggression is committed "by a person in a position effectively to exercise control over or to direct the political or military action of a State". The leadership requirement is the special feature of aggression as the crime against international peace that the perpetrator needs to satisfy at the time of the commission of the criminal offense. The so-called leadership clause contained in the Statute states that the perpetrator of the crime in question can be exclusively a person in a position effectively to exercise control over or to direct the political or military action of a State. Leadership in the context of the Statute should be understood as political and military leadership of the State engaging in the act of aggression (Kemp 2015, 180). The cited provision of the Statute is open to different interpretations about the capacity in which the perpetrator commits the crime. Various questions arise concerning the leadership requirement of the crime of aggression regarding who can fulfill this requirement. The Statute does not provide in the first place a precise answer to the question of whose actions give rise to criminal responsibility for the crime of aggression since we can differentiate between the two categories of the perpetrators of the crime in question if we consider the capacity in which they act. Those holding public offices in different branches of government and performing in their official capacity are public actors. There is no doubt that criminal responsibility for the crime of aggression is attributable to political and military leaders and other senior state officials since they can have a decisive or even an ultimate say in the political and military actions of a State (McDougall 2015, 168-183). 
Examples of such figures are presidents, prime ministers, and top military leaders such as ministers of defense and commanding generals, that is, high-ranking politicians and military officials, and also civil servants of the highest order. To determine the position of the perpetrator in a State's organization, a workable manner to proceed would be to take into account the national legislation of an alleged aggressor State in the broadest sense (including its Constitution, relevant laws, and subsidiary normative acts such as decrees, regulations, directives, instructions, and even the decision of the courts in common law jurisdictions, etc.) and practices (as far as these may deviate from the legislation), which govern the authorization of the use of force by that State, and to consider indicting individuals who occupy the posts in question accordingly (Sayapin 2014, 223). However, it is wrong to assume that leadership requirement implies collective responsibility of a leadership class or all senior government officials (Kemp $2015,215)$. The leadership requirement is one of the main but not the only criteria for attributing criminal responsibility to individuals.

\section{PRIVATE ACTORS}

The emphasis on the actual requirement for exercising effective control opens up the possibility for criminal prosecution for participation in the crime of aggression of individuals who do not occupy any formal status in the respective governments of their states. These individuals are so-called private actors since they neither act in the official capacity nor hold public office. There are divided opinions regarding the criminal responsibility of individuals who participate in the crime in question in non-official roles. On the one hand, most scholars opine that private actors, for instance, business leaders and other prominent industrialists, cannot be criminally responsible for participating in the crime of aggression since they cannot fulfill control or direct requirement (Heller 2009 , 407). These views draw support from the fact that those acting in private capacities could hardly ever find themselves in a position to control or direct the political or military machinery of a State. Hence, according to these views, individuals acting in the non-official capacity cannot be criminally responsible for the commission of the crime in question since they, by their external statuses that position them outside public offices, cannot have the decision-making power which would enable them to control or direct the behavior of a State.

On the other hand, first and foremost, reading the statutory definition of the crime of aggression or other provisions regarding the crime, one cannot find support for the claim that acting in the official capacity is the prerequisite for bearing criminal responsibility for the crime of aggression. There is no single word in the Statute supporting the view that criminal responsibility for the crime of aggression is circumscribed to public officials exclusively. The post-WWII precedents leave no doubt that individuals acting in private capacity may satisfy objective and subjective elements 
of the crime of aggression and consequently bear criminal responsibility for this crime. The United States Military Tribunals at Nuremberg dealt with the criminal prosecution of leading German Nazi industrialists in the I. G. Farben and Krupp cases for their participation in crimes against peace (May 2008, 185-204).

The concerned industrialists accused of crimes against peace were not formally members of the government but were nevertheless very closely associated with it. The essence of these cases was whether civilian heads of major companies that during WWII provided armaments and vital economic products to the Army and Navy of the Third Reich were accomplices in the waging of aggressive war (May 2008, 185).

In the I. G. Farben case, the reason for the acquittal was that the prosecution had not been able to establish beyond reasonable doubt that the activities of all the defendants related to armaments "were undertaken and carried out with the knowledge that they were thereby preparing Germany for participation in an aggressive war" (McDougall 2015, 194). What is more, the court in Farben held that the capacities in which the defendants participated in crimes against peace were that of followers, not of leaders (Farben case, 1126). When it comes to the Krupp case, the crimes against peace charges had also failed because the defendants did not satisfy the leadership requirement (Heller 2011, 188). According to the concurrence of Judge Anderson none of the defendants:

had any voice in the policies that led their nation into aggressive war; nor were any of them privies to that policy. None had any control over the conduct of the war or any of the armed forces; nor were any of the parties to the plans under which the wars were waged (USA v. Alfried Felix Alwyn Krupp von Bohlen and Halback et al., Trials of War Criminals Before the Nuremberg Military Tribunals under Control Council Law No. 10 (1950), Vol. IX (Krupp case), Anderson Concurrence, 449).

Even though the Tribunals acquitted the accused civilians in particular cases, they clarified that private actors are subject to criminal prosecution and conviction for crimes against peace, that is, the crime of aggression, on the condition that they meet all the objective and subjective elements of the crime. The Tribunal in the Krupp case even emphasized that "[w]e do not hold that industrialists, as such, could not under any circumstances be found guilty upon such charges" (Krupp case, 398). Therefore, turning to the statutory definition of the crime of aggression, while bearing in mind the aforementioned cases, considering the crime in question, the focus is on the fact that the power that the perpetrator holds enables him to control or direct the behavior of a State, notwithstanding the formal position or office he occupies in the hierarchy of government. As we have clarified, the definition of article 8 bis (1) - "a person in a position effectively to exercise control over or to direct the political or military action of a State" - concentrates on factual effective control and direction rather than formal 
status (Ambos 2014, 205). Hence, besides political and military leaders falling under the category of public actors, who can also hold informal power, economic, social, and even religious leaders may have the ability to effectively control or direct the political or military operations of a State and thus fulfill the leadership requirement which makes them responsible for the crime of aggression (Sayapin 2014, 223-226).

When it comes to the criminal responsibility of private actors for the crime of aggression, Hajdin $(2017,565)$ made a point worth considering. In a state governed like a dictatorship, private persons, such as family members, close friends, and confidants, may exert an enormous influence on a dictator holding ultimate power. These persons may be more influential in the eyes of a tyrant even than prominent party members or the highest government or military officials. For instance, when it comes to Adolf Hitler, it has been widely acknowledged that his female companion Eva Braun was the most significant figure in his life (Hajdin 2017). However, no matter the extent to which these private figures exert influence on a potentate, they cannot bear criminal responsibility since they do not have the power to control or direct the behavior of a State in question, which is another argument in favor of adopting the stricter control or direct test instead of broader shape or influence standard (Hajdin 2017).

All in all, one can conclude that both public and private actors can be held criminally responsible for the participation in the crime of aggression on the condition of meeting specified requirements laid down in the text of the Statute, albeit proving the existence of effective control of private actors over political of military actions may pose a demanding challenge for the acting prosecutor. As we have seen, the criminal responsibility of private actors for the crime in question is in line with the post-WWII precedents and the wording and intent of the Statute, and it should be therefore indisputable. However, proving effective control is the issue that concerns the procedural aspects of the crime of aggression, not the substantive ones, and thus transcends the boundaries of this analysis.

\section{MODES OF PARTICIPATION}

After examining the capacity in which the perpetrator can commit the crime of aggression, and after acknowledging that more than one perpetrator may be involved in the commission of the crime of aggression depending on the circumstances of each crime, there is a need to address the issue of complicity in the crime of aggression. If we read the statutory definition of the crime of aggression, we can wrongly conclude that only one person can bear criminal responsibility for an individual crime of aggression, thereby excluding the criminal responsibility of other wrongdoers who participated in the commission of the crime. However, that is not the case considering that the Elements leave no doubt in that regard by stipulating that more than one person can meet criminal requirements for the crime of aggression (article 8bis Elements of the 
Crime of Aggression fn. 75). The demand to extend the criminal responsibility for the crime of aggression to other perpetrators besides the perpetrator occupying the top leadership positions has been recognized in the aftermath of the Second World War. Other perpetrators cannot absolve themselves from criminal responsibility by simply claiming that they performed their actions under the orders of a potentate who had concentrated all the power in his hands, making them the mere executioners of the crime of aggression he had previously constructed in his mind,

Hitler could not make aggressive war by himself. He had to have the cooperation of statesmen, military leaders, diplomats, and businessmen (...) That they were assigned to their tasks by a dictator does not absolve them from responsibility for their acts. The relation of the leader and the follower does not preclude responsibility here any more than it does in the comparable tyranny of organized domestic crime (United States et al. v. Hermann Wilhelm Göring et al., International Military Tribunal, Trial of the Major War Criminals Before the International Military Tribunal (1950) (Nuremberg Judgment, 223).

Hence, according to the view of the IMT, being a member of an exclusive leadership circle was not a requirement for attribution of criminal responsibility for crimes against peace (McDougall 2015, 170). The perpetrators exercising effective control over a political or military action in the sense of the relevant provisions of the Statute are the members of the leadership circle or extranei.

The other question arising from the leadership requirement is whether individuals outside the leadership circle could bear the criminal responsibility and subsequently face criminal prosecution for the crime of aggression. In other words, the question is, hence, who, if any, can participate in the crime of aggression outside those belonging to the leadership circle, that is, who can be the secondary perpetrator of the crime in question. The Statute recognizes different modes of participation in the commission of crimes that fall within its jurisdiction. These modes of participation give rise to various forms of individual criminal responsibility under the Statue. The individuals who plan, prepare, initiate or execute the act of aggression are the primary or principal perpetrators of the crime. Perpetrators who participate in the commission of the crime in any other way are secondary.

Article 25 of the Statute dealing with the general rules of individual criminal responsibility also applies to the crime of aggression. According to the wording of article 25(3), there are different modes of participation in the crimes that give rise to individual criminal responsibility under the Statute. Besides the commission of the crime (article 25(3)(a)), ordering, soliciting, and inducing also give rise to criminal responsibility for the statutory crime (article 25(3)(b)). Additionally, the person is criminally responsible for the statutory crime when aids, abets, or otherwise assists in its commission or its 
attempted commission, including providing the means for its commission, on the condition that these acts are undertaken for the purpose of facilitating the commission of such a crime (article 25(3)(c)). Last but not least, article 25(3)(d) of the Statute criminalizes contribution to the commission or attempted commission of crimes by a group of persons acting with a common purpose in any other way besides those previously listed.

Nonetheless, the new definition of the crime of aggression as a leadership crime created one of the main systemic problems concerning its relationship to article 25 of the Statute dealing with individual criminal responsibility (Heinsch 2010, 733). Governing the modes of participation concerning the crime of aggression poses a special challenge because of the leadership requirement.

The abovementioned provisions seemingly allow for the prosecution of those outside the leadership circle for the crime of aggression. However, intending to reconcile the modes of participation with the leadership requirement of the crime in question, the State Parties have added the new provision to article 25(3) of the Statute that confines the modes of participation to those fulfilling the control or direct requirement. According to added article 25 (3) bis, as for the crime of aggression, the provisions of article 25 shall apply only to persons in a position effectively to exercise control over or to direct the political or military action of a State. The solution in question allows the prosecutors and the judges to employ the general provisions dealing with individual criminal responsibility, while at the same time ensures that the crime of aggression remains a leadership crime (Heinsch 2010, 732-733).

The answer to the posed question regarding the possibility of attributing criminal responsibility to outsiders should be negative since, concerning the crime in question, the Statutory provisions governing individual criminal responsibility for other forms of participation in crimes stipulate that they apply only to individuals exercising effective control of political or military actions or who are being able to direct such actions. We can conclude from this that the other modes of participation in the crime of aggression are possible, albeit confined to those belonging to the leadership circle.

Following this line of thought, individuals that do not exercise effective control over political or military actions of aggressor states cannot be prosecuted for participating in the commission of the crime of aggression because they do not satisfy the control or direct requirement. The leadership requirement applies not only to the principal or primary perpetrator but also to all other forms of participation, meaning that only a narrow class of individuals who fall under the scope of the leadership clause could incur criminal responsibility for the participation in the crime of aggression (Ambos 2013, 171). Therefore, articles 8 bis (1) and 25 (3) bis of the Statute confine the individual criminal responsibility for the crime in question to persons "in a position effectively to exercise control over or to direct the political or military action of a State" (Kress 2016, 9). 
Hence, the difference between the primary and the secondary perpetrators consists only in the acts they perform, not in the level of control they have to exercise since a certain level of control is necessary regarding all the perpetrators of the crime of aggression. Accordingly, outside the leadership circle, there is no criminal responsibility for the crime of aggression and no criminal prosecution. Despite the extent to which a person contributes to the commission of the crime of aggression, even though that person satisfies all other objective and mental elements of the crime in question, such a person will be exempted from criminal responsibility if he does not satisfy the leadership requirement. The rank-and-file soldier executing the orders of his superiors while acting as the executioner in the concentration camp can be criminally responsible for the crime of genocide or crimes against humanity; nonetheless, the same soldier cannot be held criminally responsible for the crime of aggression, according to the present solution governing the crime in question. Also, for instance, it would seem impossible to accuse of aggression the pilots carrying out air raids in foreign territory in the execution of an aggressive plan (Cassese 2007a, loc. cit.). However, the prescription of the leadership requirement, as laid down in the Statute, regarding all modes of participation has attracted heavy criticism since such an approach ensures extensive exemption from the responsibility of everybody who does not belong to the top leadership circle (Ambos 2010, 21-22).

Also, employing the leadership clause to all modes of participation regarding the crime of aggression is inconsistent with general criminal law theory since the very nature of aiding and abetting typologies consist in the fact that individuals in those categories, as a rule, do not share the characteristics or circumstances of the principal perpetrator (Kemp 2015, 180). Hence, the extension of the leadership clause to all modes of participation makes questionable the practical importance of provisions regarding individual criminal responsibility to accomplices in the crime. For example, those who would have facilitated the commission of the crime of aggression, regarding the planning of it, would be military advisers. Even though there is no doubt that they can significantly contribute to the commission of the crime, albeit no decisively, they can hardly fulfill the leadership requirement of effective control or direct since they lack the power to influence the behavior of a State.

On the other hand, the criminalization of the conduct of the low-level perpetrators for participation in the crime of aggression would not suffice the already well-established requirements stemming from international (customary) law in terms of the leadership nature of the crime (Turkovic and Vajda 2016, 867). Leaving out the difference concerning criminal responsibility for the crime of aggression and other crimes would open Pandora's box. For example, the criminal legislation of the Republic of Croatia has not confined the circle of perpetrators for the crime in question to the top leadership echelon (Turkovic and Vajda 2016, 865-867). Nevertheless, in the Republic of Croatia, domestic scientific and expert authorities have harshly criticized the 
abovementioned solution (Degan 2011, 280). The exclusion of low-level and mid-level perpetrators is also prudent for purely practical reasons. If actions of all those who participate in the execution of the act qualified subsequently as the crime of aggression, military and civil staff members in the armed forces of the aggressor State would become criminals automatically, and, what is more, many combatants and civilians would face criminal prosecution even though they acted according to the regular description of their tasks (Dinstein 2011, 142). For example, the ordinary duty of the foot soldier is to follow the orders of his superiors which includes, among other things, engaging in combat against enemies. Participating in the war is not by definition a crime if the combatants behave according to the jus in bello. While each soldier knows that it is wrong to execute civilians or engage in torture, which may give rise to criminal responsibility for crimes against humanity or war crimes, the same does not apply to the crime of aggression from the perspective of the rank-and-file soldier. To be more specific, firing shots toward enemies in the war can be a part of the act of aggression. If the soldier is faced with the fact that he may be criminally responsible for the execution of his usual and ordinary tasks, he may become reluctant to execute the orders of his superiors. Also, it would be virtually impossible to prove mens rea of mid-level and lowlevel participants needed for their conviction considering the high threshold stemming from the leadership requirement since the aggression includes policymaking at the highest level of the government (May 2008, 268).

Article 28 of the Statute has introduced the criminal responsibility of commanders and other superiors for the crimes committed by the forces under their "effective command and control, or effective authority and control". When it comes to the crime of aggression, however, the doctrine of superior (command) responsibility does not bear any practical relevance since this crime is, by definition, the crime of the highest political or military establishments, that is to say, superiors, that cannot be committed in any event by their subordinates (Weisbord 2009, 57). The doctrine of superior responsibility is thus inapplicable about the participants in the crime of aggression as a consequence of the leadership requirement. This approach is sensible considering that there is the consensus that only persons who have the decision-making power to influence policy (which usually presupposes holding a relevant position of formal governmental power) may incur criminal responsibility for the crime of aggression since it is the very principle of respondent superior, according to which superiors bear responsibility for the conduct of their subordinates (Grzebyk 2013, 211). 


\section{CONCLUSION}

The leadership requirement examined above distinguishes the crime of aggression from other crimes within the purview of the International Criminal Court, namely, genocide, crimes against humanity, and war crimes. This requirement, therefore, 'bestows' the crime of aggression its personality, and individuality.

The leadership requirement is thus the defining and special feature of the crime of aggression injected into the Rome Statute of the International Criminal Court because of the complex dual nature of the crime itself. This requirement is an objective element of the crime in question that can be considered a conduct element or a circumstance element depending on the particulars of each specific individual crime of aggression.

As regards the leadership requirement of the crime of aggression and the manner the State Parties have incorporated it in the Statue, the analyzed clause presents a compromise between the post-WWII standards and precedents of military tribunals and the contemporary scholarship and achievements of international criminal law and international (customary) law on the other hand. In plain language, the leadership clause has been incorporated with the reconciliatory aim to bring together the post-WWII precedents and understandings of contemporary international criminal law concerning the crime of aggression.

The leadership clause requires that the perpetrator occupied a defined role tempore criminis regardless of whether he had found himself in that role voluntary or involuntary from his perspective. The key to understanding the leadership requirement, thus, lies in the deciphering of the material test of effectiveness. Additionally, there must be a link between a political, military, or another position the perpetrator occupies on the one hand, and the action of a State giving rise to criminal responsibility for the crime of aggression on the other. The test of effectiveness about the ability to control or direct the political or military action of a State is satisfied when the conduct of a State giving rise to criminal responsibility for the crime of aggression could not have occurred without the commission or omission of the perpetrator. The effective control test in the context of criminal responsibility for the crime of aggression requires that the perpetrator holds power to decisively exert influence over the behavior of a State that results in the commission of the act of aggression. However, the control in question does not need to be absolute or unified in one person. Additionally, it is worth observing that both so-called public and private actors can satisfy the requirements stemming from the leadership clause. As we have seen, the leadership requirement also applies to all other modes of participation in the crime of aggression in addition to commission. Albeit the issues arising from the leadership requirement are primarily substantive and theoretical according to their nature, they have significant practical ramifications. 
First and foremost, direct or control, as a constitutive element of the leadership requirement, is a highly demanding threshold that would burden the acting prosecutors when he is in criminal proceedings in front of the Court trying to prove the participation in the crime of aggression. Last but not least, as we have seen, the leadership requirement exempts all the low-level and mid-level perpetrators from criminal responsibility for their participation in the commission of the crime of aggression. In so doing, the Statute limits criminal responsibility for this crime to a narrow class of individuals belonging to the top leadership echelons. Albeit this solution attracts harsh criticism, it is nonetheless an apt approach that satisfies international (customary) and the standards of contemporary (international) criminal law. 


\section{REFERENCES}

1. Ambos, Kai. 2010. "The Crime of Aggression after Kampala." German Yearbook of International Law 53: 463-510. Available at SSRN:

https://ssrn.com/abstract=1972173 or http://dx.doi.org/10.2139/ssrn.1972173. accessed 10 August 2021.

2. Ambos, Kai. 2013. Treatise on International Criminal Law Volume I: Foundations and General Part. Oxford: Oxford University Press.

3. Ambos, Kai. 2014. Treatise on International Criminal Law: Volume II: The Crimes and Sentencing. Oxford: Oxford University Press.

4. Bloker, Niels and Kress, Claus. 2010. „A Consensus Agreement on the Crime of Aggression: Impressions from Kampala". Leiden Journal of International Law 23: 889- 895. DOI: https://doi.org/10.1017/S0922156510000440.

5. Cassese, Antonio. 2007a. "On Some Problematical Aspects of the Crime of Aggression." Leiden Journal of International Law 20: 841-849. DOI: https://doi.org/10.1017/S0922156507004487.

6. Cassese, Antonio. 2007b. „The Nicaragua and Tadic Tests Revisited in Light of the ICJ Judgment on Genocide in Bosnia." The European Journal of International Law 18: 649-668. DOI: https://doi.org/10.1093/ejil/chm034.

7. Clark, Roger. 2009a. "The Crime of Aggression and the International Criminal Court." In The legal regime of the International Criminal Court: essays in honor of professor lgor Blishchenko: in memoriam Professor Igor Pavlovich Blishchenko (1930-2000), edited by: Jose Doria, Hans-Peter Gasser, and M. Cherif Bassiouni, 662-699. Leiden/Boston: Martinus Nijhoff Publishers.

8. Clark, Roger. 2009b. "The Crime of Aggression." In The Emerging Practice of the International Criminal Court, edited by: Carsten Stahn and Göran Sluiter, 709-723. Leiden/Boston: Martinus Nijhoff Publisher.

9. Crawford, James. 2013. State Responsibility: The General Part. Cambridge: Cambridge University Press.

10. Degan, Vladimir-Đuro. 2011. "The Responsibility for the Crime of Aggression in all its Aspects. "Proceeding of the Croatian Academy of Sciences and Arts: Social Sciences 48: 233-289.

11. Dinstein, Yoram. 2011. War, Aggression and Self-Defence. Cambridge: Cambridge University Press.

12. Drumbl, Mark. 2009. „The Push to Criminalize Aggression: Something Lost Amid the Gains?." Case Western Reserve Journal of International Law 41: 291-319.

13. Fujita, Hisakazu. 2009. "The Tokyo Trial Revisited" In The legal regime of the International Criminal Court: essays in honor of Professor lgor Blishchenko: in memoriam Professor Igor Pavlovich Blishchenko (1930-2000), edited by: Jose 
Doria, Hans-Peter Gasser, and M. Cherif Bassiouni, 23-49. Leiden/Boston: Martinus Nijhoff Publishers.

14. Gillett, Matthew. 2013. "The Anatomy of an International Crime: Aggression at the International Criminal Court." International Criminal Law Review 13: 829-864. DOI: https://doi.org/10.1163/15718123-01304003.

15. Grzebyk, Patrycja. 2013. Criminal Responsibility for the Crime of Aggression. London/New York: Routledge.

16. Hajdin, Nikola. 2017. "The Nature of Leadership in the Crime of Aggression: The ICC's New Concern?." International Criminal Law Review 17: 543-566. DOI: https://doi.org/10.1163/15718123-01703007.

17. Heinsch, Robert. 2010. „The Crime of Aggression After Kampala: Success or Burden for the Future?." Goettingen Journal of International Law 2: 713-743. DOI: 10.3249/1868-1581-2-2-Heinsch.

18. Heller, Kevin Jon. 2007. "Retreat from Nuremberg: The Leadership Requirement in the Crime of Aggression." The European Journal of International Law 18: 477-497. DOI: https://doi.org/10.1093/ejil/chm025.

19. Heller, Kevin Jon. 2011. The Nuremberg Military Tribunals and the Origins of International Criminal Law. Oxford: Oxford University Press.

20. Kemp, Gerhard. 2015. Individual Criminal Liability for the International Crime of Aggression. Cambridge: Intersentia.

21. Kress, Claus. 2016. "Introduction: The Crime of Aggression and the International Legal Order". In The Crime of Aggression: A Commentary: Volumes 1 and 2. edited by: Claus Kress and Stefan Barriga, 1-18. Cambridge: Cambridge University Press.

22. May, Larry. 2008. Aggression and Crimes against Peace. Cambridge: Cambridge University Press.

23. McDougall, Carrie. 2015. The Crime of Aggression under the Rome Statute of the International Criminal Court. Cambridge: Cambridge University Press.

24. McDougall, Carrie. 2016. "The Crimes against Peace Precedent". In The Crime of Aggression: A Commentary: Volumes 1 and 2, edited by: Claus Kress and Stefan Barriga, 49-112. Cambridge: Cambridge University Press.

25. Nerlich, Volker. 2017. "The Crime of Aggression and Modes of Liability - Is There Room Only for Principals?." Harvard International Law Journal 58: 44-47.

26. Reisinger Coracini, Astrid and Wrange, Pal. 2016. "The Specificity of the Crime of Aggression." In The Crime of Aggression: A Commentary: Volumes 1 and 2, edited by: Claus Kress and Stefan Barriga, 307-350. Cambridge: Cambridge University Press.

27. Sayapin, Sergey. 2014. The Crime of Aggression in International Criminal Law: Historical Development, Comparative Analysis, and Present State. The Hague: T.M.C. Asser Press. 
28. Talmon, Stefan. 2009. "The Responsibility of outside Powers for Acts of Secessionist Entities". International and Comparative Law Quarterly 58: 493-517. DOI: $10.1017 /$ S0020589309001171.

29. Turkovic, Ksenija and Munivrana Vajda, Maja. 2016. "Croatia." In The Crime of Aggression: A Commentary: Volumes 1 and 2, edited by: Claus Kress and Stefan Barriga, 863-879. Cambridge: Cambridge University Press.

30. Weisbord, Noah. 2009. „Conceptualizing Aggression." Duke Journal of Comparative \& International Law 20: 1-68.

31. Zimmermann, Andreas and Freiburg, Elisa, 2015. „Article 8bis Crime of Aggression." In The Rome Statute of the International Criminal Court: $A$ Commentary, edited by: Otto Triffterer and Kai Ambos 580- 618. Oxford: C.H. Beck/Hart/Nomos.

\section{LEGAL CASES}

1. Military and Paramilitary Activities in and Against Nicaragua (Nicar. v. the US), 1986 International Court of Justice 14, (June 27).

2. Prosecutor v. Dusko Tadic, Case No. IT-94-1-A, Judgment of the Appeals Chamber, 15 July 1999 (Tadic case).

3. United States et al. v. Hermann Wilhelm Göring et al., International Military Tribunal, Trial of the Major War Criminals Before the International Military Tribunal (1950) (Nuremberg Judgment).

4. USA v. Alfried Felix Alwyn Krupp von Bohlen and Halback et al., Trials of War Criminals Before the Nuremberg Military Tribunals under Control Council Law No. 10 (1950), Vol. IX (Krupp case).

5. USA v. Carl Krauch et al., Trials of War Criminals Before the Nuremberg Military Tribunals Under Control Council Law No. 10 (1952), Vols. VII-VIII (Farben case).

6. USA v. Wilhelm von Leeb et al., Trials of War Criminals Before the Nuremberg Military Tribunals Under Control Council Law No. 10 (1951), Vols. X-XI (High Command case).

\section{LEGAL INSTRUMENTS}

1. Elements of Crimes, https://www.icc-cpi.int/nr/rdonlyres/336923d8-a6ad-40ecad7b-45bf9de73d56/0/elementsofcrimeseng.pdf, accessed 10 August 2021.

2. The Rome Statute of the International Criminal Court, https://www.icccpi.int/resource-library/documents/rs-eng.pdf, accessed 10 August 2021. 